\title{
Original Paper \\ Diversity of Scleria (Cyperaceae) in Amazonian restinga in Pará state, Brazil
}

\author{
Layla Jamylle Costa Schneider ${ }^{1,3,4}$ \& André dos Santos Bragança Gil ${ }^{2}$
}

\begin{abstract}
This study aims to contribute to the knowledge on the taxonomy of Scleria in sandy coastal plains (restinga) in Pará state, Brazil. Material deposited in the herbaria of Museu Paraense Emílio Goeldi (MG), Embrapa Amazônia Oriental (IAN), and Instituto de Estudos Costeiros da Universidade Federal do Pará (HBRA) were analyzed and species were identified using relevant literature, protologues, and types available online. We recorded nine species of Scleria for restinga in the state: Scleria bracteata, S. gaertneri, S. hirtella, S. interrupta, S. macrophylla, S. microcarpa, S. reticularis, S. secans, and S. violacea. An identification key, descriptions, illustrations, and comments about diagnostic characters and geographic distribution are provided for these species.
\end{abstract}

Key words: neotropics, sandy coast, Sclerieae, taxonomy.

\section{Resumen}

El objetivo de este estudio fue contribuir al conocimiento sobre la taxonomía de Scleria en las llanuras costeras arenosas (restinga) del estado de Pará, Brasil. Se analizó el material depositado en los herbarios del Museu Paraense Emílio Goeldi (MG), Embrapa Amazônia Oriental (IAN), y del Instituto de Estudos Costeiros da Universidade Federal do Pará (HBRA); se determinaron las especies utilizando literatura, obras originales y tipos disponibles en línea. Se registraron nueve especies de Scleria en la restinga del estado: Scleria bracteata, S. gaertneri, S. hirtella, S. interrupta, S. macrophylla, S. microcarpa, S. reticularis, S. secans, y S. violacea. Se proporciona una clave de identificación, descripciones, ilustraciones y comentarios sobre los caracteres de diagnóstico y distribución geográfica para las especies.

Palabras clave: neotrópico, costa arenosa, Sclerieae, taxonomía.

\section{Introduction}

Scleria P.J.Bergius is one of the largest genera of Cyperaceae, with ca. 260 species, and in Brazil, it is the fourth most species-rich genus of the family, with 76 species, including 14 endemic and 11 species that occur in all regions of the country (Govaerts 2019; Flora do Brasil 2020, under construction). The genus is subdivided into four subgenera, $S$. subg. Browniae (C.B.Clarke) C.B.Clarke (1 section), $S$. subg. Hypoporum (Nees) C.B.Clarke (3 sect.), $S$. subg. Scleria (12 sect.), and S. subg. Trachylomia
(Nees) Bauters (1 sect.) (Bauters et al. 2016, 2018). Scleria occurs in the tropics and is found mostly in open forested areas, secondary vegetation, swamps, savannas, campinaranas, and restingas (Bauters et al. 2016; Flora do Brasil 2020, under construction).

Restinga areas are defined as sandy coastal communities from the Quaternary period that are closely associated with the ocean and nearby beaches, dunes, and depressions (Araújo \& Henriques 1984; Brasil 1993). Along the Brazilian coast in Amazonia, restinga occurs discontinuously for $1,500 \mathrm{~km}$ in

\footnotetext{
${ }^{1}$ Universidade Federal Rural da Amazônia e Museu Paraense Emilio Goeldi, Prog. Pós-graduação em Ciências Biológicas, Av. Perimetral 1901, Terra Firme, 66077-830, Belém, PA, Brazil.

${ }^{2}$ Museu Paraense Emílio Goeldi, Coord. Botânica, Av. Perimetral 1901, Terra Firme, 66077-830, Belém, PA, Brazil.

${ }^{3}$ ORCID: <https://orcid.org/0000-0002-0373-454X>

${ }^{4}$ Author for correspondence: laylaschneider11@gmail.com
} 
the states of Amapá, Pará, and Maranhão (Suguio \& Tessler 1984; Amaral et al. 2008). Pará contains approximately $40 \%$ of the restinga in this region, which is represented by plains interspersed with islands, peninsulas, and bays (Amaral et al. 2008; Silva et al. 2010). This ecosystem is undergoing great anthropogenic impact from tourism, real estate speculation, and the removal of sand for building construction (Bastos et al. 2013).

In Pará state restinga studies were conducted in the area of vegetation formations (Santos \& Rosário 1988; Bastos 1988, 1995; Santos et al. 2003; Santos \& Bastos 2014), phytosociology (Costa-Neto et al. 2001), and floristics (Amaral et al. 2001), notably Cyperaceae, which is the richest and most abundant family in this ecosystem (Amaral et al. 2001; Costa Neto et al. 2001; Santos et al. 2003). Additionally, there are taxonomic studies about Cyperaceae in Pará, researched by Nunes et al. (2016), who studied the flora of the cangas of Serra dos Carajás, Schneider et al. (2017) and Maciel-Silva et al. (2018), who published a synopsis of Rhynchospora and a flora of Eleocharis for restinga, respectively.

Considering the diversity of Scleria in Brazil, the importance of restinga and the fragility of this coastal ecosystem in the face of anthropogenic pressures, this study aims to contribute to the knowledge of Scleria in the restinga of Pará state.

\section{Material and Methods}

The examined specimens were from the main herbaria located in Pará state: MG, IAN, and HBRA (acronyms according to Thiers, continuously updated). These specimens come from municipalities (counties) of Pará that containing restinga: São Caetano de Odivelas, Curuçá, Marapanim, Maracanã, Salinópolis, São João de Pirabas, Quatipuru, Tracuateua, Bragança, Augusto Corrêa, and Viseu (Fig. 1). We also collected material in the municipalities of Marapanim and Maracanã. Collecting and processing the herbarium specimens followed the standard techniques as described in Rotta et al. (2008).

Species identification was made by consulting some literatures (Core 1936; Kessler 1987; Camelbeke \& Goetghebeur 1998, 2002) and the following websites with digitized protologues: Biodiversity Heritage Library (2018); Botanicus Digital Library (2018); and Open Library (2018). Similarly, for some species, digitized herbarium types at B, BM, $\mathrm{M}, \mathrm{PI}$, and PR were consulted (acronyms according to Thiers, continuously updated). The abbreviations of the protologues, periodicals, and authors are based on the websites Tropicos (2018) and World Checklist of Selected Plant Families (2018).

The morphological descriptions of the genus and species were made based on the material examined, and in the dimensions of the fruit are excluded the hypogynium and the stylobase. When the specimens from restinga of Pará did not have a structure of taxonomic relevance, the information was taken from the literature or additional herbarium specimens and included in a complementary description below the main description. The terminology used for the leaves, inflorescences, spikelets, and fruits follows Ahumada (2007), Ahumada \& Vegetti (2009), and Espinoza et al. (2016).

Geographic distribution data are from information on labels of examined material, literature (Acevedo-Rodríguez \& Strong 2012; Camelbeke \& Goetghebeur 1998; Kessler 1987; Nunes \& Prata 2013), and the websites World Checklist of Selected Plant Families (2018), Flora do Brasil 2020 (under construction), and SpeciesLink (2018). Habitats are based on the classification of vegetation formations by Santos \& Bastos (2014) and information on labels of examined material.

\section{Results and Discussion}

Nine species of Scleria were recorded for restinga of Pará: Scleria bracteata Cav., S. gaertneri Raddi, S. hirtella Sw., S. interrupta Rich., S. macrophylla J.Presl \& C.Presl, S. microcarpa Nees ex Kunth, S. reticularis Michx., S. secans (L.) Urb., and $S$. violacea Pilg.

For restinga in Brazil, the states of Sergipe (Oliveira et al. 2014) and Pará have the most species in common (Scleria gaertneri, S. hirtella, S. interrupta, S. microcarpa, and S. secans). Scleria bracteata is on some species lists for the Northeast Region of Brazil; however, it has not been recorded in Sergipe (Maranhão - Serra et al. 2016; Rio Grande do Norte - Almeida Jr. et al. 2006; Pernambuco - Zickel et al. 2007; and Bahia - Britto et al. 1993). In the northern region of Brazil, Amaral et al. (2008) studied Amazonian restinga in Pará and Amapá and reported six Scleria species [S. cyperinoides C.B.Clarke $=$ S. martii (Nees) Steud., S. hirtella, S. latifolia Sw., S. lithosperma (L.) Sw., S. macrogyne C.B.Clarke, and $S$. microcarpa]; however, these authors did not provide vouchers, making it impossible to confirm the occurrence of some of these species. In restinga of Brazil's southeast region, only three species have been recorded, S. gaertneri, S. hirtella, and $S$. myricocarpa Kunth (Espírito Santo - Valadares et al. 2011; São Paulo - Martins et al. 2008), and 
two of these species also occur in restinga in Pará. In restinga of Brazil's southern region, five species have been recorded, Scleria distans, S. gaertneri, S. georgiana Core ssp. australis A.C.Araújo, $S$. latifolia, and S. uleana Boeck. (Paraná - Marques \& Oliveira 2004; Santa Catarina - Affonso et al. 2015), of which only $S$. gaertneri is found in the restinga of Pará.

Scleria P.J.Bergius, Kongl. Vetensk. Acad. Handl. 26: 142.1765.

Herbs, erect or scandent, perennial or annual, cespitose or solitary, rhizomatous or rhizome absent. Stem trigonous, glabrous to pubescent, angles unarmed or scabrous. Sheaths membranous to chartaceous, winged or not winged; contraligule with or without a membranaceous appendix; ligule present or absent. Leaf blades often cauline and reduced at the base, linear to lanceolate, margins unarmed or scabrous, surfaces glabrous to hirsute; apex entire or pseudopremorse. Involucral bract one per inflorescence, linear to lanceolate, similar to the leaves or sometimes to the glumes. Inflorescence terminal, paniculiform or in interspaced congested fascicles (spiciform). Spikelets unisexual, androgynous or subandrogynous (male glumes are empty). Flowers unisexual, staminate flowers with 1-3 stamens, pistillate flowers with 3 stigmas. Cupule subtending the fruit, entire or three-lobed, margin glabrous or ciliate, persistent on the fruit or spikelet. Hypogynium developed or reduced (papillose region at the base of the fruit), entire or three-lobed when developed, lobes laciniate, rounded, oblong or triangular. Fruit a nutlet, globose, subglobose or ovoid, smooth, tuberculate, reticulate or rugulose, glabrous or pubescent. Stylobase (stylopodium) persistent, deciduous, or absent on the distal part of the fruit.

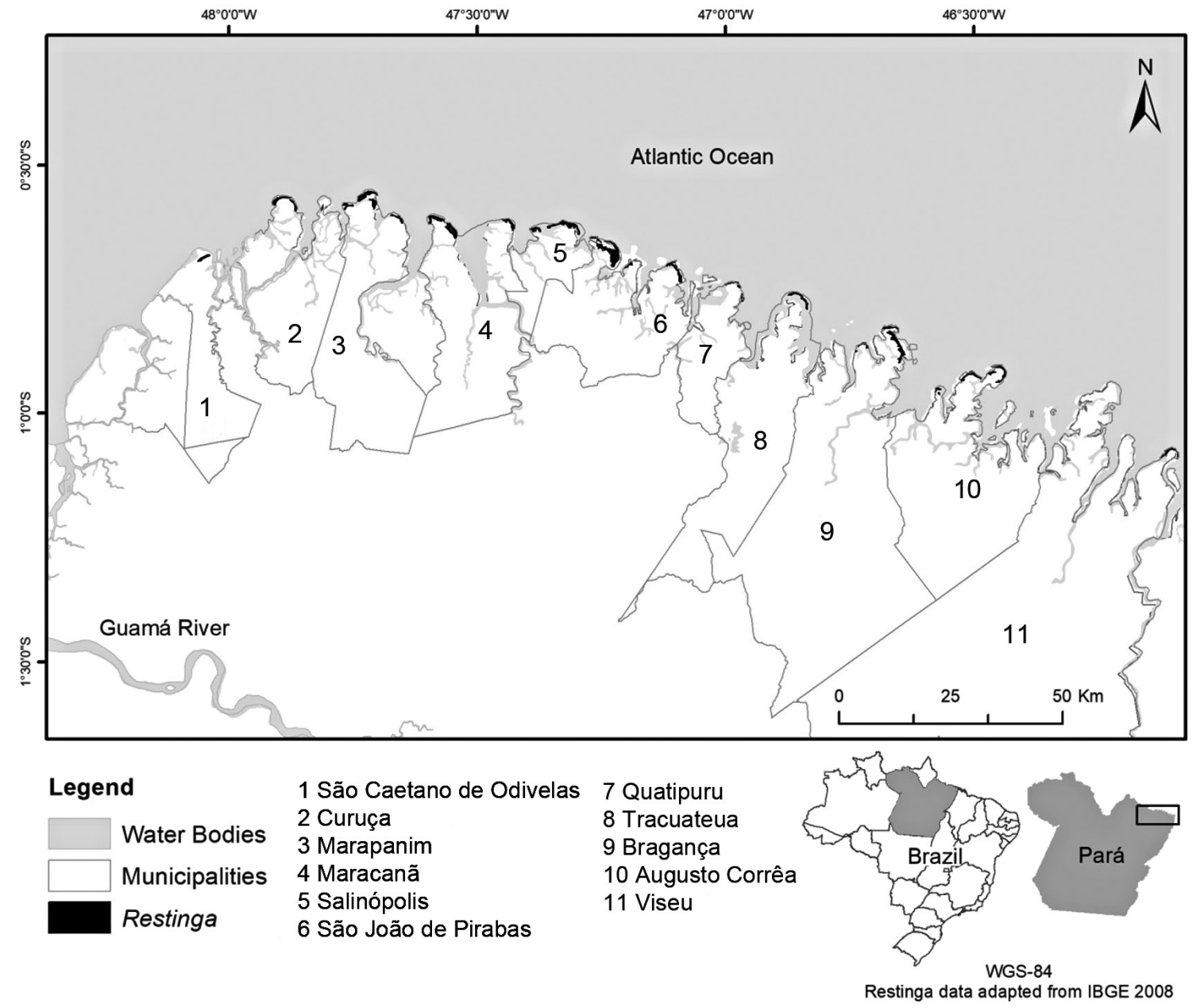

Figure 1 - Location of the study area. Adapted from IBGE (2008). 


\section{Identification key to the species of Scleria in restinga in Pará state, Brazil}

1. Inflorescence spiciform; androgynous spikelets and hypogynium reduced (in Scleria subgenus Hypoporum)

1'. Inflorescence paniculiform; subandrogynous or unisexual spikelets and hypogynium developed (in $S$. subg. Scleria) .

2. Nutlet surface smooth

3. Scleria hirtella

2'. Nutlet surface papillose-rugulose.

4. Scleria interrupta

3. Inflorescence with subandrogynous spikelets in proximal part and with staminate spikelets in distal part; lobes of the hypogynium laciniate [in S. section Schizolepis (Schrad. ex Nees) C.B.Clarke] 1. Scleria bracteata

3'. Inflorescence with subandrogynous and/or unisexual spikelets mixed in proximal and distal parts; lobes of the hypogynium rounded, oblong or triangular....

4. Contraligule with membranaceous appendix; ligule present [in S. sect. Hymenolytrum

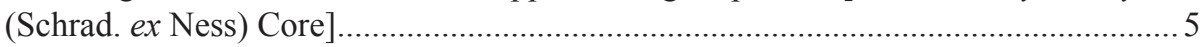

4'. Contraligule without membranaceous appendix or inconspicuous; ligule absent ........ 6

5. Sheaths winged; nutlet puberulous...

9. Scleria violacea

5'. Sheaths not winged; nutlet glabrous.

8. Scleria secans

6. Leaves with pseudopremorse apex; cupule persistent on fruit [in $S$. sect.

Ophryoscleria (Nees) C.B.Clarke].....

6'. Leaves with entire apex; cupule persistent on spikelet ................................ 8

7. Leaf blades $2.2-3.2 \mathrm{~cm}$ wide, surfaces glabrous

5. Scleria macrophylla

7'. Leaf blades $0.7-1.2 \mathrm{~cm}$ wide, surfaces puberulents

6. Scleria microcarpa

8. Glumes with ciliate margin; stamen 1; nutlet smooth; lobes of the hypogynium rounded (in $S$. sect. Scleria) ........2. Scleria gaertneri

8'. Glumes with glabrous margin; stamens 3; nutlet reticulated-foveate; lobes of the hypogynium oblong (in $S$. sect. Foveolidia Raf.)........

7. Scleria reticularis

1. Scleria bracteata Cav., Icon. 5: 34. 1799.

Fig. 2a

Herbs, 1-1.5 m tall, climbing, perennial, solitary, rhizomes knotted. Stem (2.5-)3-6 mm wide, glabrous to glabrescent, angles unarmed. Sheaths $1.8-5 \mathrm{~cm}$ long, chartaceous, not winged; contraligule cuneate, ciliate, membranous appendage absent; ligule present. Leaf blades (16.1-)20.7-33.2 × 0.7-1.5 cm, lanceolate, margin scabrous, abaxial surface glabrous to glabrescent, adaxial surface glabrescent with puberulous midrib, apex inconspicuously pseudopremorse. Involucral bract $6.8-21.1 \times 0.3-1.2 \mathrm{~cm}$, lanceolate, similar to the leaves. Inflorescence paniculiform. Spikelets subandrogynous (in proximal part) and staminate (in distal part); glumes reddish brown to blackish, glabrescent, with inconspicuous trichomes on the margins and midrib. Subandrogynous spikelets $5-7(-8) \times 1.2-2.5 \mathrm{~mm}$, ellipsoid. Staminate spikelets 3-4 × 0.5-1.5(-1.9) $\mathrm{mm}$, narrowly ellipsoid to linear; flowers with 3 stamens. Cupule three-lobed, margin glabrous, persistent on the spikelet. Hypogynium wine colored to black, threelobed, lobes laciniate. Nutlet 1.7-2 × 1.7-2.5 mm, globose, white, rugulose, puberulous. Stylobase absent.

Material examined: Augusto Corrêa, Ilha do Rodrigues, 01 ${ }^{\circ} 2^{\prime} 00^{\prime}$ 'S, 46³0'44”W, 3.VIII.2010, fl., M.J. Silva et al. 104 (HBRA). Marapanim, 1,5 km do trevo para

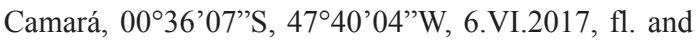
fr., L. Schneider et al. 133 (MG).

Additional material examined: BRAZIL. PARÁ: Maracanã, $00^{\circ} 47^{\prime} 56.7^{\prime}$ 'S, 47²8'25.4”W, IV.1977, fl. and fr., E. Oliveira 6632 (MG).

Scleria bracteata is characterized by its conspicuous, scabrous, extremely sharp leaf margins that aid in the scandent habit of the species. It has a distinct female (subandrogynous spikelets) and male (staminate spikelets) panicles; this type of zoned inflorescence is unique to the species. The subandrogynous panicles are proximal and the staminate panicles are distal. However, in the nodes 
between these panicles zones, there are sometimes inflorescence subunits with both types of spikelets. Frequently, the subandrogynous spikelets are sessile and the staminate spikelets are pedicellate. Scleria bracteata may resemble S. myricocarpa, which is also in section Schizolepis and occur in the Southeast and South of Brazilian restinga, by the pseudopremorse leaves apex, paniculiform inflorescences, with subandrogynous and staminate spikelets and lobes of the hypogynium laciniate. Although, Scleria myricocarpa lack the zoned inflorescence and have reticulate-rugose nutlets.

The species occurs in Mexico, Belize, Costa Rica, Guatemala, Honduras, Nicaragua, Trinidad and Tobago, French Guiana, Guyana, Suriname, Venezuela, Bolivia, Colombia, Ecuador, Peru, Brazil, and Paraguay. In Brazil, this species occurs in all regions, except the southern region, and the states of Acre, and Rondônia. In restinga in Pará, it occurs in herbaceous marshes, fields between dunes, and open shrub formations.

2. Scleria gaertneri Raddi, Accad. Lucchese Sci., Lett. Ed. Arti 2: 331. 1823.

Fig. 2b

Herbs, 61-70.5 cm tall, erect, perennial, cespitose or solitary, rhizomes knotted. Stem 3-6 $\mathrm{mm}$ wide, glabrous, angles scabrous. Sheaths 3-7.9 cm long, papyraceous, winged; contraligule cuneate, ciliate, membranaceous appendix absent; ligule absent. Leaf blades 28.2-37.6 × 0.7-1.1(1.4) $\mathrm{cm}$, linear to lanceolate, margin scabrous near the apex, abaxial surface glabrous with scabrous midrib, adaxial surface glabrous with two scabrous veins parallel to the midrib, apex entire. Involucral bract 9-16 × 0.5-0.7 cm, linear to lanceolate, similar to the leaves. Inflorescence paniculiform. Spikelets subandrogynous and staminate; glumes reddish brown to chestnutbrown with wine-colored spots, glabrescent, margin ciliate. Subandrogynous spikelets 2.5-3.5 $\times 1.5-2.5 \mathrm{~mm}$, ellipsoid. Staminate spikelets 3-3.5 $\times 1-1.5 \mathrm{~mm}$, narrowly ellipsoid; flowers with 1 stamen. Cupule three-lobed, margin glabrous, persistent on spikelet. Hypogynium white with purple to completely brown margin, threelobed, lobes rounded. Nutlet $1.2-3 \times 2-2.3 \mathrm{~mm}$, subglobose, laterally flat, white to a dark wine color, smooth, glabrous with sparse trichomes near the hypogynium. Stylobase absent.

Selected material: Bragança, península de Ajuruteua, 0054'58.4'S, 4640'58.9'W, 28.III.2009, fl. and fr., E.S. Oliveira \& H.J. Santos 118 (HBRA). Salinopólis,
Cuiarana, transecto II do projeto Itarana/MPEG, 20.IX.2013, fl. and fr., A. Gil et al. 322 (MG).

Additional material examined: BRAZIL. PARÁ: Paragominas, Fazenda Agresta, 02 59 '45'S, 47²1'10”W, 5.III.1980, fl. and fr., I.C. Vieira 29 (MG).

Scleria gaertneri can be identified by its winged sheath, paniculiform inflorescence, and subglobose, smooth nutlet. Nutlet color is highly variable, even on the same fruit, including white, wine-colored, and blackish tones. On some specimens studied, pubescence was observed on parts of the inflorescence (such as the rachis and rachilla), sheath, and involucral bract. The disposition of the staminate and subandrogynous spikelets did not exhibit a uniform pattern; however, the subandrogynous spikelets were frequently near the rachis axils (branching zone) and had pedicels ca. $1.5 \mathrm{~mm}$ long, while the staminate spikelets were usually further from the rachis axils and had pedicels $2-3 \mathrm{~mm}$ long. Collections from Bragança and Salinópolis had galls that deformed the spikelets and fruits. In this material, the spikelets were elongated (up to $5 \mathrm{~mm}$ long) and the fruits were ovoid, differing from the subglobose, flattened fruits that are characteristic of the species (Fig. 2b).

The species occurs in Mexico, Belize, Costa Rica, El Salvador, Guatemala, Honduras, Nicaragua, Panama, Cuba, Haiti, Jamaica, Puerto Rico, Trinidad and Tobago, French Guiana, Guyana, Suriname, Venezuela, Bolivia, Colombia, Ecuador, Guatemala, Peru, Brazil, Argentina, Paraguay, tropical Africa, and Madagascar. Widely distributed in Brazil (all states). In restinga in Pará, this species is found in fields between dunes, open shrub formations, and along margins of restinga forest.

3. Scleria hirtella Sw., Prodr.: 19. 1788. Fig. 2c Herbs, 33.6-51.9 cm tall, erect, annual, cespitose, rhizome absent. Stem $0.5-1.2 \mathrm{~mm}$ wide, glabrescent, angles unarmed. Sheaths $2.3-2.5 \mathrm{~cm}$ long, membranaceous, not winged; contraligule rounded to oblique, ciliate, membranaceous appendix present (inconspicuous); ligule absent. Leaf blades $6.8-14 \times 0.1-0.2 \mathrm{~cm}$, linear, margin scabrous near apex, abaxial and adaxial surface glabrous, apex entire. Involucral bract 0.4-2.9 $\times$ $0.03-0.1 \mathrm{~cm}$, lanceolate, similar to the glumes. Inflorescence spiciform. Spikelets androgynous 2.5-4 × 0.6-1.5 mm, ellipsoid; glumes brown to reddish-brown, glabrescent with pubescent midrib, margin glabrous; flowers with 2 stamens. Cupule entire, margin glabrous, persistent on 
spikelet. Hypogynium reduced. Nutlet 1.5-1.8 × 1.1-1.5 mm, subglobose, white to reddish, smooth, glabrous, base trigonous, with 3-5 pores on each face. Stylobase absent.

Material examined: Bragança, península de Ajuruteua, 0050'11'S, 46 37'09'W, 22.VI.2008, fl. and fr., E.S. Oliveira 50 (HBRA). Salinópolis, Cuiarana, próximo ao PIII do Projeto Itarana/MPEG, 20.IX.2013, fl. and fr., A. Gil et al. 340 (MG). São Caetano de Odivelas, Ilha de Taquari, 25.VIII.1998, fl. and fr., M.N. Bastos et al. 1909 (MG).

Additional material examined: BRAZIL. PARÁ: Marajó, Rio Camará, Jutuba, IX.1902, fl. e fr., V.C. Miranda 3092 (IAN, MG).

Scleria hirtella is similar to S. interrupta. These species belong to $S$. sect. Hypoporum. Scleria hirtella has glabrescent stems, bracts and glumes, and globose, smooth nutlets (Fig. 2c). The smooth surface of the nutlets distinguishes it the most from the other species, which have nutlets with a papillose-rugulose surface (Fig. 2d) (see comments under $S$. interrupta). Scleria hirtella is similar to $S$. distans that occurs in restinga in the South Region of Brazil. Scleria distans is a rhizomatous species and lacks pores at the base of the nutlets, whereas $S$. hirtella is cespitose with pores at the base of the fruits.

The species occurs in Mexico, Belize, Guatemala, Honduras, Panama, Cuba, Dominican Republic, Haiti, Jamaica, Porto Rico, Trinidad and Tobago, Guyana, French Guiana, Suriname, Venezuela, Bolivia, Colombia, Ecuador, Peru, Brazil, tropical Africa, and Madagascar. Widely distributed in Brazil (all states). In restinga in Pará, this species is found in fields between dunes and open shrub formations.

\section{Scleria interrupta Rich., Actes. Soc. Hist. Nat.} Paris 1: 112. 1792.

Fig. 2d

Herbs, $17-52.1 \mathrm{~cm}$ tall, erect, annual, cespitose. Stem $0.5-1.5 \mathrm{~mm}$ wide, pilose to glabrous, angles unarmed. Sheaths (1.7-)2-6.8 cm long, membranaceous, not winged; contraligule truncate to oblique, ciliate, membranaceous appendix present (inconspicuous); ligule absent. Leaf blades (2.3-)4.9-17.6 × 0.1-0.2 cm, linear, margin scabrous near apex, abaxial and adaxial surfaces pilose to glabrous, apex entire. Involucral bract $0.3-0.5 \times 0.05-0.1 \mathrm{~cm}$, linear, similar to the glumes. Inflorescence spiciform. Spikelets androgynous $2.5-4 \times 0.5-1.1 \mathrm{~mm}$; glumes chestnut-brown, sometimes chestnut-brown with wine-colored spots and red mucro, glabrescent with pubescent midrib, margin glabrous; flowers with 2 stamens. Cupule entire, margin glabrous, persistent on spikelet. Hypogynium reduced. Nutlet $1.2-1.5(-2) \times 1-1.3 \mathrm{~mm}$, globose to obovate, white, sometimes white with longitudinal gray lines, papillose-rugulose, glabrous, base trigonous with 4-5 pores on the faces. Stylobase absent.

Selected material: Bragança, península de Ajuruteua, $00^{\circ} 50^{\prime} 1$ 'S, 46 $37^{\circ} 17^{\prime \prime}$ W, 5.VI.2007, fl. and fr., L.O. Santos et al. 346 (HBRA, MG). Marapanim, Vila de Marudá, praia do Crispim, 15.VI.1991, fl. and fr., M.N. Bastos et al. 972 (MG). Salinópolis, Cuiarana, Ilha de Itarana, próximo à sede da Fazenda, 21.XI.2013, fl. and fr., A. Gil et al. 353 (MG). Viseu, Fernandes Belo, vila Apeú-Salvador, 24.XI.2015, fl. and fr., U. Mehlig 1677 (HBRA, MG).

Scleria interrupta has spiciform inflorescences, as observed in S. hirtella. In addition, it is characterized by its leaf blades that are pilose on both surfaces, rarely glabrous, glumes with trichomes on the midrib and papillose-rugulose nutlets (Fig. 2d) (see comments about S. hirtella).

The species occurs in Mexico, Belize, Costa Rica, Guatemala, Honduras, Nicaragua, Panama, Cuba, Dominican Republic, French Guiana, Guyana, Suriname, Venezuela, Ecuador, and Brazil. In Brazil, this species has been recorded for the states of Pará, Mato Grosso, Ceará, Rio Grande do Norte, Paraíba, Pernambuco, Alagoas, Sergipe, Bahia, and Minas Gerais. In restinga in Pará, it occurs in herbaceous marshes, fields between dunes, and open shrub formations.

5. Scleria macrophylla J.Presl \& C.Pres1, Reliq. Haenk. 1(3): 200. 1828.

Fig. 2e

Herbs, erect, perennial, rhizome not seen. Stem $0.5-1 \mathrm{~cm}$ wide, glabrous, angles scabrous. Sheaths 4-9 cm long, chartaceous, winged; contraligule cuneate, glabrous, membranaceous appendix absent; ligule absent. Leaf blades 23 $30.7 \times 2.2-3.2 \mathrm{~cm}$, linear to lanceolate, margins scabrous near the apex, abaxial and adaxial surfaces glabrous, apex pseudopremorse. Involucral bract $3.1-12.2 \times 0.5-1.1 \mathrm{~cm}$, linear to lanceolate, similar to the leaves. Inflorescence paniculiform. Spikelets subandrogynous and staminate; glumes chestnutbrown to glaucous, puberulent, margin ciliate. Subandrogynous spikelets $4.2-5 \mathrm{~mm}$ long, widely elliptic. Staminate spikelets $4.3-5.4 \times 1.9-2.1 \mathrm{~mm}$, ellipsoid; flowers with 3 stamens. Cupule not seen. Hypogynium not seen. Nutlet not seen. Stylobase not seen.

Complementary description: Plants 1-3 m tall, rhizomes knotted (Core 1936). Cupule threelobed, margin ciliate, persistent on fruit (J.J. Pipoly 
11291 - MG). Hypogynium light chestnut-brown, three-lobed, lobes rounded (A.F.S. Souza et al. 14 HBRA). Nutlet 2.6-3.5 × 4-4.5 mm, globose, white to brownish yellow, smooth, glabrous (A.F.S. Souza et al. 14 - HBRA). Stylobase present, persistent, coniform, chestnut-brown. (A.F.S. Souza et al. 14 - HBRA).

Material examined: Marapanim, Vila de Marudá, praia do Crispim, 15.VI.1991, fl., M.N. Bastos et al. 1016 (MG).

Additional material examined: BRAZIL. PARÁ: Bragrança, Jiquiri, 9.X.2012, fl. and fr., A.F.S. Souza et al. 14 (HBRA). Gurupá, arredores do aeroporto, 7.VIII.1968, fl. and fr., M. Silva 1470 (MG). GUIANA. DEMERARA REGION: Naamryck Canal, $\pm 8 \mathrm{~km}$ SE of Naamryck Public Rd, just W of Lookout village, $06^{\circ} 50^{\prime} \mathrm{N}, 58^{\circ} 25^{\prime} \mathrm{W}$, 31.III.1988, fl. and fr., J.J. Pipoly 11291 (MG).

Scleria macrophylla is notable among the species in restinga in Pará for its robust size, wide leaves with a pseudopremorse apex, and puberulent glumes. The material examined of the restinga lacked nutlets, which are fundamental when determining species of Scleria. However, fertile collections made in the proximity of the Bragança restinga (A.F.S. Souza et al. 14 - HBRA) allowed the material to be identified, together with the type (Haenke PR25264) which has a sterile inflorescence and was useful to compare with the restinga material.

The species occurs in México, Belize, Costa Rica, Guatemala, Honduras, Nicaragua, Panama, Cuba, Jamaica, Trinidad and Tobago, French Guiana, Guyana, Suriname, Venezuela, Bolivia, Colombia, Ecuador, Peru, and Brazil. In Brazil, this species occurs in nearly all regions but has not been recorded in the states of Amapá, Pernambuco, Alagoas, Sergipe, Espírito Santo, and Rio de Janeiro, nor the southern region. In restinga in Pará, it occurs in fields between dunes.

6. Scleria microcarpa Nees ex Kunth, Enum. Pl. 2: 341.1837.

Fig. $2 f$

Herbs, ca. $90 \mathrm{~cm}$ tall, erect, perennial, rhizomatous. Stem 1.5-4 mm wide, glabrous, angles scabrous. Sheaths 3.5-9 cm long, papyraceous, winged; contraligule acute, ciliate to glabrous, membranaceous appendix absent; ligule absent. Leaf blades 13-23.6 × 0.7-1.2 cm, lanceolate, margins scabrous near the apex, abaxial surface puberulent, adaxial surface puberulent, with two prominent, usually scabrous, parallel veins, apex pseudopremorse. Involucral bract $7-19 \times$ ca. 0.4 $\mathrm{cm}$, lanceolate, similar to the leaves. Inflorescence paniculiform. Spikelets subandrogynous and staminate; glumes chestnut-brown with red lines, glabrescent with inconspicuous trichomes on the midrib, margin glabrous to ciliate. Subandrogynous spikelets $1.5-2.5 \times 1.3-1.6 \mathrm{~mm}$, ellipsoid. Staminate spikelets $1.5-2.3 \times 1.1-1.3 \mathrm{~mm}$, ellipsoid; flowers with 3 stamens. Cupule entire to slightly three-lobed, margin ciliate, persistent on the fruit. Hypogynium chestnut-brown, threelobed, lobes rounded. Nutlet 1.2-1.7 × 1.5-2 mm, ovoid, light brown to grayish, smooth, glabrous. Stylobase present, deciduous, coniform, beige to chestnut-brown.

Material examined: Marapanim, próximo ao trevo para Camará, 00³6'23'’S, 4740'27'W, 06.VI.2017, fl. and fr., L. Schneider et al. 118 (MG).

Additional examined material: BRAZIL. PARÁ: Salvaterra, Lagoa do Hotel Pousada dos Guarás, reserva ecológica de Salvaterra, 16.I.1992, fl. and fr., N.A. Rosa 5573 (MG).

Among the species of Scleria in restinga in Pará, S. microcarpa is notable for its non-showy inflorescence, ovoid nutlet with a deciduous stylobase, and cupule with a ciliate margin that is persistent on the fruit and covering the hypogynium (Fig. 2f). Scleria microcarpa is similar to S. uleana, which occurs in restinga in the southern region of Brazil, because of its non-showy inflorescence, cupule with a ciliate margin that is persistent on the fruit, ovoid nutlet, and deciduous stylobase. However, Scleria uleana is scandent with lax inflorescence subunits and S. microcarpa is an erect herb with a subcontracted inflorescence subunits.

The species occurs in Mexico, Belize, Costa Rica, Guatemala, Honduras, Nicaragua, Panama, Cuba, Dominican Republic, Haiti, Jamaica, Porto Rico, Trinidad and Tobago, French Guiana, Guyana, Suriname, Venezuela, Bolivia, Colombia, Ecuador, Peru, Brazil, and Paraguay. In Brazil, it is recorded in all states except Rio Grande do Sul. In restinga in Pará, this species occurs in open shrub formations.

7. Scleria reticularis Michx., F1. Bor. -Amer. 2: 167. 1803.

Fig. $2 \mathrm{~g}$

Herbs, (18-)25-48.2 cm tall, erect, perennial, cespitose. Stem 1.5-2.5 wide, hirsute, angles scabrous near the apex. Sheaths 3-6.7 cm, membranaceous, winged; contraligule cuneate to rounded, ciliate, membranaceous appendix present (inconspicuous); ligule absent. Leaf blades (5-)15$22.2 \times 0.2-0.4 \mathrm{~cm}$, linear, margins scabrous at the apex, abaxial and adaxial surfaces glabrous, apex entire. Involucral bract $3-9.2 \times 0.1-0.3 \mathrm{~cm}$, linear, similar to the leaves. Inflorescences paniculiform. 
Spikelets subandrogynous and staminate; glumes brown with wine-colored margin, glabrescent, the midrib with inconspicuous trichomes, margin glabrous. Subandrogynous spikelets $5-5.5 \times 1-2$ $\mathrm{mm}$, ellipsoid. Staminate spikelets $3-3.5 \times 0.7-1$ $\mathrm{mm}$, linear to narrowly ellipsoid; flowers with 3 stamens. Cupule three-lobed, margin glabrous, persistent on the spikelet. Hypogynium white to light brown, three-lobed, lobes oblong. Nutlet $1.3-2 \times 1.5-1.8 \mathrm{~mm}$, globose, white to blackish with white dots, reticulated-foveate, pubescent. Stylobase absent.

Selected material: Bragança, península de Ajuruteua, salinas dos Roques (Jabuti), 0054'53'S, 46 40'29'W, 20.V.2007, fl. and fr., L.O. Santos et al. 297 (HBRA, IAN, MG). Maracanã, Ilha de Maiandeua, Fortalezinha, 3.VII.1992, fl. and fr., L.C. Lobato et al. 536 (MG). Marapanim, $1,5 \mathrm{~km}$ do trevo para Camará, $00^{\circ} 36^{\prime} 07^{\prime}$ 'S, $47^{\circ} 40^{\prime} 04^{\prime}$ 'W, 6.VI.2017, fl. and fr., L. Schneider et al. 129 (MG). Salinópolis, Praia do Atalaia, 20.IX.2013, fl. and fr., A. Gil et al. 317 (MG).

Scleria reticularis differs from the other species in restinga in Pará by its reticulatedfoveate, pubescent nutlets and hypogynium with oblong lobes (Fig. 2g). Frequently, the pedicels of the subandrogynus spikelets are short and covered by bracteoles. Its rachises have winged margins, with a glabrescent and reddish surface, which extend from the base of the inflorescence branch to the base of the spikelet.

The species occurs in the U.S.A., Brazil, Bolivia, and Colombia. In Brazil, it is recorded for the states of Roraima, Pará, and Goiás, and the Northeast Region. In the restinga in Pará, this species grows in herbaceous marshes, fields between dunes, and open shrub formations.

8. Scleria secans (L.) Urb., Symb. Antill. 2: 169. 1900.

Schoenus secans L., Syst. Nat. 10(2): 865. 1759.

Fig. $2 \mathrm{~h}$

Herbs, scandent, perennial, rhizome not seen. Stem 3.5-4 mm wide, glabrous, angles scabrous. Sheaths 3.4-8.7 cm long, chartaceous to papiraceous, not winged; contraligule cuneate, ciliate, membranaceous appendix present; ligule present. Leaf blades 9.7-25.6 $\times 0.4-0.7 \mathrm{~cm}$, linear, margins sharp scabrous, abaxial surface glabrescent with scabrous midrib, adaxial surface glabrescent with inconspicuous trichomes on the midrib, apex entire. Involucral bract $(8-) 9-10.5(-23.4) \times 0.4-$ $0.5 \mathrm{~cm}$, linear, similar to the leaves. Inflorescences paniculiform. Spikelets unisexual; glumes reddish chestnut-brown to glaucous, glabrescent, margin glabrous. Pistillate spikelets $5-6 \times 1-1.5 \mathrm{~mm}$, ellipsoid. Staminate spikelets 3.5-5.2 × 0.6-1.5 $\mathrm{mm}$, ellipsoid; flowers with 3 stamens. Cupule entire to three-lobed, margin glabrous, persistent on the spikelet. Hypogynium brown, entire. Nutlet 2-3 $\times 2,5-3 \mathrm{~mm}$, globose to ovoid, white with blackish spots, smooth, glabrous. Stylobase absent.

Complementary description: $2-5 \mathrm{~m}$ tall, rhizomatous (Nunes \& Prata 2013).

Material examined: Bragança, península de Ajuruteua, salinas dos Roques/Jabuti, $00^{\circ} 55^{\prime} 36^{\prime \prime} \mathrm{S}, 46^{\circ} 40^{\prime} 12^{\prime \prime} \mathrm{W}$, 22.V.2005, fl. and fr., R.E.S.A. Nascimento et al. 258 (HBRA).

Additional examined material: BRAZIL. PARÁ: Melgaço, Floresta Nacional de Caxiuanã, Estação Científica Ferreira Penna, $01^{\circ} 46^{\prime} 42^{\prime \prime S}$, $51^{\circ} 25^{\prime} 30^{\prime \prime} \mathrm{W}$, 22.IV.2017, L. Schneider et al. 90 (MG).

Scleria secans is distinct from the other species in restinga of Pará state because of its scandent habit, conspicuously scabrous stem and leaves, sheath with a conspicuous membranaceous appendix, and ovoid, smooth nutlet (Fig. 2h). On the material examined, there were lateral shoots at the nodes and some contraligules lacked a membranaceous appendix. Rarely, near the hypogynium, sparse trichomes were observed on the nutlet.

It occurs in Mexico, Belize, Costa Rica, Guatemala, Honduras, Nicaragua, Panama, Cuba, Dominican Republic, Haiti, Jamaica, Porto Rico, Trinidad and Tobago, French Guiana, Guyana, Suriname, Venezuela, Colombia, Ecuador, Peru, Brazil, Argentina, and Paraguay. Widely distributed in Brazil (all states). In restinga in Pará, this species occurs in open shrub formations and along the edges of restinga forest.

9. Scleria violacea Pilg., Bot. Jahrb. Syst. 30(1): 145. 1901.

Fig. $2 \mathrm{i}$

Herbs, $86.2-90 \mathrm{~cm}$ tall, erect to scandent, perennial, solitary, rhizomes knotted. Stem $1.8-5(-7.5) \mathrm{mm}$ wide, glabrous, angles unarmed to scabrous. Sheaths 6-11 cm long, papyraceous, winged; contraligule rounded, glabrous, membranaceous appendix present; ligule present. Leaf blades (15-)28-40.5 × 0.5-1.4 cm, linear, margins scabrous, abaxial surface glabrous with scabrous midrib, adaxial surface glabrescent with pubescent midrib and two scabrous veins parallel to the midrib, apex entire. Involucral bract (2.5-)3.8-13 $\times 0.5-1.2 \mathrm{~cm}$, linear, similar to the leaves. Inflorescence paniculiform. Spikelets unisexual; glumes chestnut-brown with purple to blackish spots, glabrous, sometimes with 
trichomes at the apex, margin glabrous. Pistillate spikelets 5-8 $\times 0.8-1.5 \mathrm{~mm}$, lanceolate to ellipsoid. Staminate spikelets $3.8-5 \times 0.7-1.2 \mathrm{~mm}$, linear to narrowly ellipsoid; flowers with 3 stamens.
Cupule entire, margin glabrous, persistent on spikelet. Hypogynium white to livid, three-lobed, lobes triangular. Nutlet 2-3.7 $\times 2-2.7 \mathrm{~mm}$, ovoid to subglobose, white to livid with grayish spots,
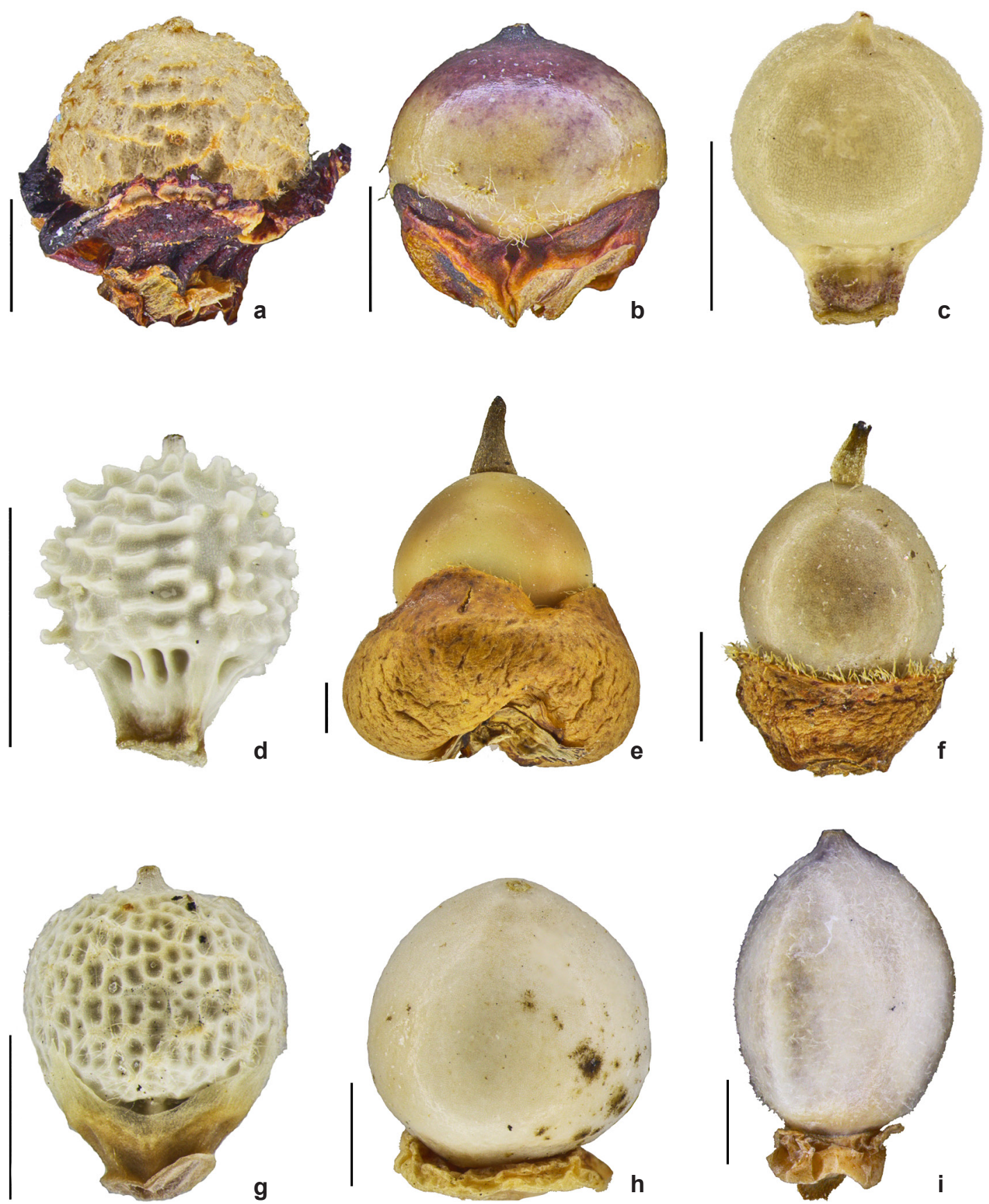

Figure 2 - a-i. Nutlets of Scleria species that occur in the restinga of the Pará state - a. Scleria bracteata; b. S. gaertneri; c. S. hirtella; d. S. interrupta; e. S. macrophylla; f. S. microcarpa; g. S. reticularis; h. S. secans; i. S. violacea. Scale bar: 1 mm. (a. E. Oliveira 6632; b. I.C. Vieira 29; c. V.C. Miranda 3092; d. L.O. Santos 385; e. M. Silva 1470; f. N.A. Rosa 5573; g. L. Schneider 127; h. L. Schneider 90; i. J.F. Maciel-Silva 201). 
surface smooth to slightly rugulose, puberulous. Stylobase absent.

Selected material: Maracanã, Ilha de Maiandeua, 26.X.2000, fl. and fr., D.C.T. Costa et al. 89 (MG). Marapanim, Vila de Marudá, praia do Crispim, 15.VI.1991, fl. and fr., M.N. Bastos et al. 1043 (MG).

Additional examined material: BRAZIL. PARÁ: Melgaço, Floresta Nacional de Caxiuanã, Estação Científica Ferreira Penna, 145'30”S, 53²9'29”W, 24.IV.2017, fl. and fr., J.F. Maciel-Silva et al. 201 (MG).

Scleria violacea has short inflorescence internodes, which gives the appearance of a single terminal inflorescence subtended by three involucral bracts. For this species, the membranaceous appendix at the apex of contraligule is conspicuous, making it easy to identify in combination with the ligule of trichomes and ovoid nutlet (Fig. 2i). Its pistillate spikelets are frequently at the base of the rachilla, sessile or with a short pedicel covered with two bracteoles, and its staminate spikelets are usually pedicellate (characteristic inflorescence of the sect. Hymenolytrum), with pedicels $0.8-2 \mathrm{~mm}$ long. Scleria violacea is similar to S. macrogyne, which is cited by Amaral et al. (2008) for restinga in Pará. Scleria violacea differs by its inflorescences with lax spikelets, and inconspicuous wings sheaths ( $v s$. inflorescences with densely grouped spikelets, and conspicuous wings sheaths).

The species occurs in French Guiana and Brazil. In Brazil, it is reported in the states of Pará, Tocantins, Maranhão, Piauí, Bahia, and Mato Grosso. In the restinga in Pará, this species occurs in fields between dunes and open shrub formations.

\section{Acknowledgments}

We thank CNPq for awarding the scholarship to the first author (148387/2016-0); the curators of MG, IAN, and HBRA for the material examined; and the curators of B, BM, M, PI and PR by type information; Nathan Smith and Louis Forline for reviewing the English; and Milena Andrade for making our map. This study was financed in part by the Coordenação de Aperfeiçoamento de Pessoal de Nível Superior - Brasil (CAPES) - Finance Code 001.

\section{References}

Acevedo-Rodríguez P \& Strong MT (2012) Catalogue of seed plants of the West Indies. Smithsonian Contributions to Botany 98: 1-1192.

Affonso R, Zani A \& Brummitt NA (2015) Diversity of Scleria (Cyperaceae) in Santa Catarina, Brazil. Rodriguésia 66: 353-367.
Ahumada O (2007) Las especies argentinas y paraguayas del género Scleria P.J.Bergius (Cyperaceae). Estudio taxonómico y tipología de la sinflorescencia. PhD Thesis. Universidad Nacional del Litoral, Santa Fe. 431p.

Ahumada O \& Vegetti AC (2009) Inflorescence structure in species of Scleria subgenus Hypoporum and subgenus Scleria (SclerieaeCyperaceae). Plant Systematics and Evolution 281: 115-135.

Almeida Jr EBD, Zickel CS \& Pimentel RMM (2006) Caracterização e espectro biológico da vegetação do litoral arenoso do Rio Grande do Norte. Revista de Geografia 23: 67-86.

Amaral DD, Santos JUM, Bastos MNC \& Costa DCT (2001) A vegetação da Ilha Canela, município de Bragança, Pará, Brasil. Boletim do Museu Paraense Emilio Goeldi 17: 389-402.

Amaral DD, Prost MT, Bastos MNC, Costa-Neto SV \& Santos JUM (2008) Restingas do litoral amazônico, estados do Pará e Amapá, Brasil. Boletim do Museu Paraense Emilio Goeldi 3: 35-67.

Araújo DSD \& Henriques RPB (1984) Análise florística das restingas do estado do Rio de Janeiro. In: Lacerda LD, Araujo DSD, Cerqueira R \& Turcq B (orgs.) Restingas: origem, estrutura e processos. CEUFF, Niterói. Pp. 159-193.

Bastos MNC (1988) Levantamento florístico em restinga arenosa litorânea na Ilha MaiandeuaPará. Boletim do Museu Paraense Emilio Goeldi, Série Botânica 4: 159-173.

Bastos MNC (1995) A importância das formações vegetais da restinga e do manguezal para as comunidades pesqueiras. Boletim do Museu Paraense Emilio Goeldi, Série Antropologia 11: 41-56.

Bastos MNC, Santos JUM, Amaral DD \& Costa-Neto SV (2013) Alterações ambientais de origem natural e antrópica na vegetação litorânea do nordeste do estado do Pará. In: Prost MT \& Mendes AC (eds.) Ecossistemas costeiros: impactos e gestão ambiental. 2 $2^{\text {a }}$ ed. Museu Paraense Emílio Goeldi, Belém. Pp. 25-34.

Bauters K, Asselman P, Simpson DA, Muasya AM, Goetghebeur P \& Larridon I (2016) Phylogenetics, ancestral state reconstruction, and a new infrageneric classification of Scleria (Cyperaceae) based on three DNA markers. Taxon 65: 444-466.

Bauters K, Goetghebeur P, Asselman P, Meganck K \& Larridon I (2018) Molecular phylogenetic study of Scleria subgenus Hypoporum (Sclerieae, Cyperoideae, Cyperaceae) reveals several species new to science. Plos One 13: e0203478.

Biodiversity Heritage Library (2018) Available at $<$ http://www.biodiversitylibrary.org/>. Access on 10 December 2018. 
Botanicus Digital Library (2018) Available at <http:// www.botanicus.org/>. Acess on 22 August 2018.

Brasil (1993) Ministério do Meio Ambiente, Conselho Nacional de Meio Ambiente, CONAMA. Resolução CONAMA no 010/93. Estabelece os parâmetros básicos para análise dos estágios de sucessão de Mata Atlântica. Diário Oficial da União N. 209, 03 nov 1993, seção I, Brasília. Pp. 16497-16498.

Britto IC, Queiroz LD, Guedes MLS, Oliveira ND \& Silva LD (1993) Flora fanerogâmica das dunas e lagoas do Abaeté, Salvador, Bahia. Sitientibus 11: 31-46.

Camelbeke K \& Goetghebeur P (1998) Scleria. In: Berry PE, Yatskievych K \& Holst BK (eds.) Flora of the Venezuelan Guayana. Vol. IV. Missouri Botanical Garden Press, St. Louis. Pp. 641-659.

Camelbeke K \& Goetghebeur P (2002) The genus Scleria (Cyperaceae) in Colombia. An updated checklist. Caldasia 24: 259-268.

Core EL (1936) The American species of Scleria. Brittonia 2: 1-115.

Costa-Neto SV, Pereira JO, Bastos MNC, Santos JUM \& Amaral DD (2001) Fitossociologia das formações herbáceas da restinga do Crispim, Marapanim, Pará. Boletim Museu Paraense Emílio Goeldi, Série Botânica 17: 161-186.

Espinoza P, Chacón-Madrigal E, Sánchez E \& GómesLaurito J (2016) Key to the species of the genus Scleria (Cyperaceae) in Costa Rica based on the morphology of achenes. Phytotaxa 284: 81-107.

Flora do Brasil 2020 (em construção) Instituto de Pesquisas Jardim Botânico do Rio de Janeiro. Available at $<$ http://floradobrasil.jbrj.gov.br/>. Access on 27 November 2018.

Govaerts R (2019) World Checklist of Scleria. Facilitated by the Royal Botanic Gardens, Kew. Available at <http://apps.kew.org/wcsp/ namedetail.do?name_id $=265158>$. Access on 27 March 2019.

IBGE (2008) Mapa de vegetação da Amazônia Legal. Available at $<$ http://downloads.ibge.gov. br/downloads geociencias.htm>. Access on 05 October 2018.

Kessler JW (1987) A treatment of Scleria (Cyperaceae) for North America north of Mexico. SIDA, Contributions to Botany 12: 391-407.

Maciel-Silva JF, Nunes CS \& Gil ASB (2018) The genus Eleocharis (Cyperaceae) in the restinga of Pará state, Brazil. Rodriguésia 69: 1813-1824.

Marques MCM \& Oliveira PEAM (2004) Fenologia de espécies do dossel e do sub-bosque de duas Florestas de Restinga na Ilha do Mel, sul do Brasil. Revista Brasileira de Botânica 27: 713-723.

Martins SE, Rossi L, Sampaio PDSP \& Magenta MAG (2008) Caracterização florística de comunidades vegetais de restinga em Bertioga, SP, Brasil. Acta Botanica Brasilica 22: 249-274.
Nunes CDS, Bastos MNC \& Gil ASB (2016) Flora of the cangas of the Serra dos Carajás, Pará, Brasil: Cyperaceae. Rodriguésia 67: 1329-1366.

Nunes IR \& Prata APN (2013) Scleria. In: Prata APN, Amaral MCE, Farias MCV \& Alves MV (orgs.) Flora do Sergipe. Vol. 1. Triunfo, Aracajú. Pp. 203-218.

Oliveira EVS, Lima JF, Silva TC \& Landim MF (2014) Checklist of the flora of the Restingas state of Sergipe, Northeast Brazil. Check List 10: 529-549.

Open Library (2018) Available at <https://openlibrary. org/>. Access on 13 August 2018.

Rotta E, Beltrami LCC \& Zonta M (2008) Manual de prática de coleta e herborização de material botânico. Documentos 173. Embrapa Florestas, Colombo. 31p.

Santos JUM \& Bastos MNC (2014) Flores e frutos das restingas do estado do Pará. Ed. da UFRA Universidade Federal Rural da Amazônia, Belém. 246p.

Santos JUM \& Rosário CS (1988) Levantamento da vegetação fixadora de dunas de Algodoal-PA. Boletim do Museu Paraense Emílio Goeldi, Série Botânica 4: 133-151.

Santos JUM, Amaral DD, Gorayebe IS, Bastos MNC, Secco RS, Costa-Neto SV \& Costa DCT (2003) Vegetation of the Jabotitiua-Jatium protected environmental area, municipality of Viseu, Pará, Brazil. Acta Amazonica 33: 431-444.

Schneider LJC, Bastos MNC, Costa-Neto SV \& Gil ASB (2017) Sinopse do gênero Rhynchospora Vahl (Cyperaceae) nas restingas do estado do Pará, Brasil. Rodriguésia 68: 653-670.

Serra FCV, Lima PB \& Almeida Jr EBD (2016) Species richness in restinga vegetation on the eastern Maranhão state, Northeastern Brazil. Acta Amazônica 46: 271-280.

Silva MS, Mehlig U, Santos JUM \& Menezes MPM (2010) The coastal restinga vegetation of Pará, Brazilian Amazon: a synthesis. Revista Brasileira de Botânica 33: 563-573.

SpeciesLink (2018) Available at $<$ http://www.splink. org.br/>. Access in 25 October 2018.

Suguio K \& Tessler MG (1984) Planícies de cordões litorâneos quaternários do Brasil: origem e nomenclatura. In: Lacerda LD, Araujo DSD, Cerqueira R \& Turcq B (orgs.) Restingas: origem, estrutura e processos. CEUFF, Niterói. Pp. 15-25.

Thiers B [continuously updated] Index Herbariorum: a global directory of public herbaria and associated staff. New York Botanical Garden's Virtual Herbarium. Available at $<$ http://sweetgum.nybg. org/science/ih/>. Access on 25 October 2018.

Tropicos (2018) Missouri Botanical Garden. Available at $<$ https://www.tropicos.org $>$. Access on 12 November 2018.

Valadares R, Souza F, Castro N, Peres A, Schneider S \& Martins M (2011) Levantamento florístico de um 
brejo-herbáceo localizado na restinga de Morada do Sol, município de Vila Velha, Espírito Santo, Brasil. Rodriguésia 62: 827-834.

World Checklist of Selected Plant Families (2018) Facilitated by the Royal Botanic Gardens, Kew. Published on the internet. Available at $<$ http:// apps.kew.org/wcsp/>. Access on 12 November 2018.

Zickel CS, Almeida Jr EBD, Medeiros DPW, Lima PB, Souza TMS \& Barros Lima A (2007) Magnoliophyta species of restinga, state of Pernambuco, Brazil. Check List 3: 224-241.

\section{List of exsiccatae}

Albim EMS 16 (9). Bastos MN 813 (7), 972 (4), 1016 (5), 1043 (9), 1143 (9), 1258 (9), 1909 (3). Bragança VAN 72 (2). Gil A 317 (7), 322 (2), 329 (4), 340 (3), 353 (4). Costa DTC 89 (9). Lobato LC 536 (7), 1068 (7). Maciel-Silva JF 201 (9). Mehlig U 73 (2), 122 (2), 166 (7), 331 (7), 1016 (4), 1677 (4). Miranda VC 3092 (3). Nascimento RESA 120 (2), 258 (8). Oliveira E 6632 (1). Oliveira ES 50 (3), 118 (2), 177 (2). Oliveira JN 6 (2). Pereira ASS 81 (9). Pipoly JJ 11291 (5). Rodrigues LKM 8 (9), 13 (9), 26 (7), 65 (9), 66 (9). Rosa NA 5573 (6). Sena RX 13 (9). Santos LO 26 (4), 288 (2), 297 (7), 303 (4), 346 (4), 351 (7), 385 (4). Schneider L 90 (8), 118 (6), 119 (9), 125 (9), 127 (7), 129 (7), 132 (9), 133 (1). Silva M 1470 (5). Silva MJ 40 (4), 104 (1). Souza AFS 14 (5). Souza CCS (MG203902) (9). Vieira IC 29 (2). 